U.S. DEPARTMENT OF HEALTH AND HUMAN SERVICES

CENTER FOR DISEASE CONTROL

NATIONAL INSTITUTE FOR OCCUPATIONAL SAFETY AND HEALTH

CINCINNATI, OHIO 45226

HEALTH HAZARD EVALUATION REPORT

HE 77-74-720

OTTENHEIMER \& SONS, INC.

DAWSON SPRINGS, KENTUCKY

JLY 1980

I. SUMMARY

At the request of the Amalgamated Clothing \& Textile Workers Union (ACTWU), the National Institute for Occupational Safety and Health (NIOSH) conducted a health hazard evaluation at Ottenheimer \& Sons, Inc., Dawson Springs, Ky., to evaluate reports of skin and eye irritation and loss of fingernails among employees working with formaldehyde-containing textiles. Work area air samples were analyzed for vaporous formaldehyde and fabric samples were analyzed for latent formaldehyde content. The medical evaluation included a medical questionnaire and skin examination of symptomatic production employees.

The airborne formaldehyde concentration ranged from 0.13 to $0.57 \mathrm{ppm}$ (mean $0.25,5.0 .+0.14$ ), all below the NIOSH recommended ceiling value of $1.0 \mathrm{ppm}$. The latent formaldehyde levels in four fabrics tested ranged from 580 to $938 \mathrm{ppm}$. The latent formaldehyde content of these fabrics decreased $86-91 \%$ three weeks after the initial determination. These data indicate that as storage time increases the amount of available formaldehyde and, hence, potential worker exposure decreases. There were reports of eye, respiratory tract, and skin irritation, rash, and one case of loss of fingernails. The pattern of skin irritation and rash was somewhat different from that usually found in formaldehyde dermatitis.

Although all environmental measurements were below the NIOSH recommended standard, workers may have been exposed to irritating concentrations of formaldehyde since similar health effects have been reported at the levels of formaldehyde measured. Potential exposures may be minimized by providing sufficient time for fabrics to "air" before being handled. 
Page 2 - Health Hazard Evaluation Determination Report No. 77-74

II. INTRODUCTION

Under Section 20(a)(6) of the Occupational Safety \& Health Act of 1970 NIOSH investigates the toxic effects of substances found in the workplace. In April 1977, NIOSH received a request from an officer of the ACTWU to evaluate health problems experienced by employees exposed to manufacturing processes utilizing formaldehyde-containing textiles at Ottenheimer \& Sons, Inc., Dawson Springs, Ky. An initial walk-through was done on June $22-23,1977$ by NIOSH industrial hygienists and an interim report was issued 12-29-77. A follow-up medical/environmental survey was done March 13, 1978 by two dermatologists from the University of Cincinnati, a NIOSH occupational health nurse, and an industrial hygienist. A letter with a brief summary of the results of this visit was sent January 24, 1979.

III. BACKGROUND

Ottenheimer \& Sons, Inc. manufactures uniforms for establishments such as fast-food franchises and hospitals. Materials are brought in ready for cutting from a variety of suppliers. The manufacturing process is divided into three areas: (1) Cutting - Here, rolls of cloth are spread by machine on large tables and tracing paper is placed on top of the cloth layers and marked. The cloth is then cut by an automatic cutter with a blade which moves in an up and down motion. (2) Sewing Room This area comprises most of the floor space in the main plant and is subdivided into six sections for the various phases of assembly of the uniforms; and (3) the Shipping Department.

There are approximately 210 employees at the plant, 175 of which are production workers. The majority of the production workers are women. There is one shift per day. Wages are paid mostly on a piece-work basis but there are some hourly workers. The production rate averages 12,000 uniforms per week.

The types of fabrics used are primarily polyesters, with lesser quantities of polyester/cotton blends and nylon blends. Three durable press fabrics including "MEDA," "Valid Poplin," and "Resolute," were reported by the workers to be of primary concern. The durable press characteristics of these fabrics are imparted by a glyoxal-based resin, 1,3-dimethy lol-4, 5-dihydroxy-2-imidazolidinone (DMDHEU).

IV. EVALUATION DESIGN AND METHODS

A. Industrial Hygiene

Aerometric testing was conducted on June 23, 1977, and March 13, 1978, to evaluate worker exposure to formaldehyde. The formaldehyde samples 
Page 3 - Health Hazard Evaluation Determination Report No. 77-74

were collected using calibrated personal sampling pumps operating at 1.0 $\mathrm{L} / \mathrm{min}$ and $15 \mathrm{ml}$ of $\mathrm{I} \%$ sodium bisulfite solution contained in a graduated midget impinger. Each sample was prepared and analyzed for formaldehyde according to NIOSH spectrophotometric method P\&CAM No. 125. Bulk cloth samples were collected for latent formaldehyde content determination using a method supplied by Burlington Industries. Portions of the bulk were suspended over water in sample jars, sealed, and placed in an oven for 20 hours at $490 \mathrm{C}$. The solutions were analyzed spectrophotometrically after the addition of chromotropic acid and compared to a calibration curve based on known formaldehyde concentrations.

\section{B. Medical}

The medical evaluation (March, 1978) consisted of (1) a walk-through survey of the entire plant to observe the production process, and (2) interviews with all (26) known symptomatic production employees. A brief examination of exposed skin was made on those employees whose medical history suggested possible dermatitis.

A comprehensive medical study designed to try to determine the basic mechanism responsible for the reported symptoms was considered but rejected as not feasible.

\section{Evaluation Criteria}

NIOSH recommends a ceiling limit of 1 ppm "based on reports of irritation, objectionable odor, and disturbed sleep for a few employees on exposure to formaldehyde at $0.3 \mathrm{ppm}$ and of more general complaints at concentrations exceeding 1 ppm. "4 The primary health effects of exposure to formaldehyde are irritation of the respiratory tract, eyes, and skin. Eye and upper respiratory tract irritation has been reported in workers exposed to concentrations of formaldehyde at levels much lower than $1 \mathrm{ppm} .2,7$ Recent studies have found that formaldehyde induced nasal cancer in rats exposed to high levels ( $15 \mathrm{ppm}$ ) of formaldenyde over a long period of time. 3 An excess cancer risk in humans has not been observed; epidemiologic studies to investigate this possibility are planned.

V. RESULTS AND DISCUSSION

\section{A. Environmental}

The airborne formaldehyde concentrations measured on June 23, 1977, and March 13, 1978, are presented in Table $I$. The concentrations ranged from 0.13 to $0.57 \mathrm{ppm}$ (mean 0.32, S.D. + 0.17 ) and 0.14 to $0.26 \mathrm{ppm}$ (mean 0.18, S.D. + 0.05), respectively. By comparison, NIOSH recommends a $1.0 \mathrm{ppm}$ ceiling value. 4 Eye and upper respiratory tract irritation has been reported at concentrations similar to those measured at this plant. 2, 7 
Page 4 - Health Hazard Evaluation Determination Report No. 77-74

The latent formaldehyde content of four fabric samples is presented in Table II. The latent formaldehyde content was measured three weeks after the initial determination and showed a decrease of $86-91 \%$. Although these data are limited, they show a definite correlation between the age of the resin treated fabric and latent formaldehyde content. Storage of the fabric in a ventilated area for a determined time period, therefore, should significantly reduce the potential for worker exposure to vaporous formaldehyde.

\section{B. Medical}

All 26 known symptomatic employees were interviewed. The median age was 30; median years with the company, 6. All were women. Several of the symptomatic employees gave histories of "sinus" problems which were present prior to their starting work at this plant. The majority (15) of employees seen were most concerned about skin irritation and/or rashes, but most of these also had burning of the eyes, and/or irritation of the nose and throat. A large number (14) had chest tightness or chest pain. One employee's main concern was of chronic ear infections. There was one report of loss of fingernails. In general, symptoms were reported to be work-related and were usually rapid in onset and resolution with many of the symptoms occurring within 15 minutes of starting to work with certain materials and resolving within 2-3 hours of leaving the plant. Few skin rashes were seen during this visit, but while those seen were erythematous (red) and slightly scaly, they were not eczematous (characterized by erythema, small papules (bumps) and vesicles, oozing and crusting). Individual descriptions of rashes were also more of transient erythemas and itchy patches or papules than of eczematous dermatitis. Several gave histories suggestive of urticaria (hives). The hands, arms, neck, and face were the areas most commonly affected. More widespread rashes were described by some workers. Symptomatic workers reported that they experienced more symptoms when working with certain fabrics.

As evidenced by the employees' descriptions of their rashes and the dermatologists' examinations, the predominant pattern was different from the eczematous lesions usually seen in formaldehyde dermatitis. Whether these rashes were irritant or allergic in nature was not determined.

VI. RECOMMENDATIONS AND CONCLUSIONS

Reported health effects were associated primarily with the handling of certain fabrics such as "MEDA", "Valid Poplin" and "Resolute". Although the basic mechanism (irritant or allergic) responsible for the reported rashes and skin irritation was not determined, a likely source is the latent formaldehyde present in the fabric. The latent formaldehyde content of the four fabrics tested decreased significantly ( 86 - 91\%) after a 3-week storage time. Thus, potential exposures can be minimized by allowing sufficient time for fabrics to "air" before being handled. 
Page 5 - Health Hazard Evaluation Determination Report No. 77-74

\section{REFERENCES}

1. American Conference of Governmental Industrial Hygienists Documentation of the Threshold Limit Value for Substances in Workroom Air, Cincinnati, Onio, 1977.

2. Bourne, H.G., and S. Seferian, Formaldehyde in Wrinkle-Proof Apparel. Produces... Tears for Milady, Industrial Med. and Surgery 28:232 233, 1959.

3. Chemical Industrial Institute of Toxicology, Progress Report on CIIT Formaldehyde Studies (January 16, 1980), Leon Goldberg, President, Research Triangle Park, N.C.

4. Criteria for a Recommended Standard... Occupational Exposure to Formaldehyde 1976, HEW (NIOSH) Publication No. 77-126.

5. Fisher, Alexander, Contact Dermatitis, 2nd edit. Lea \& Febiger, Philadelphia, 1978.

6. NIOSH Manual of Analytical Methods, 2nd edit., vol. 1, DHEW (NIOSH) publication No. 77-157A.

7. Schuck, E.A., et al: Arch Environ. Health 13:570, 1966.

VIII. ACKNOWLEDGEMENTS

Report Prepared By:

Linda Frederick, R.N. Occupational Health Nurse

Medical Section, HETAB

DSHEFS/NIOSH

Cincinnati, Ohio

Industrial Hygiene Consultant: John $R$ Kominsky Industrial Hygienist Industrial Hygiene Section Hazard Evaluations \& Technical Assistance Branch

Cincinnati, Ohio

Survey Conducted By:

Dawn Tharr

Industrial Hygienist

Industrial Hygiene Section

Hazard Evaluations \& Technical

Assistance Branch

Cincinnati, Onio

C. Paul Roper

Regional Consultant, Region IV Occupational Safety and Health

NIOSH, Atlanta, Georgia 
Page 6 - Health Hazard Evaluation Determination Report No. 77-74

\begin{tabular}{|c|c|}
\hline & $\begin{array}{l}\text { Richard Rycroft, M.D. } \\
\text { Visiting Scientist } \\
\text { Formerly with the Department } \\
\text { of Environmental Health } \\
\text { University of Cincinnati } \\
\text { Cincinnati, Onio }\end{array}$ \\
\hline$\cdot$ & $\begin{array}{l}\text { Edward A. Emmett, M.D. } \\
\text { Formerly Associate Professor of } \\
\text { Environmental Health, Medicine } \\
\text { and Dermatology } \\
\text { University of Cincinnati } \\
\text { Cincinnati, Ohio }\end{array}$ \\
\hline Originating office: & $\begin{array}{l}\text { Hazard Evaluation and Technical } \\
\text { Assistance Branch } \\
\text { Division of Surveillance, Hazard } \\
\text { Evaluation, and Field Studies } \\
\text { Cincinnati, Onio }\end{array}$ \\
\hline Report Typed By: & $\begin{array}{l}\text { Dorothy Chandler } \\
\text { Clerk/Typist } \\
\text { Medical Section } \\
\text { Hazard Evaluation and Technical } \\
\text { Assistance Branch } \\
\text { Cincinnati, Ohio }\end{array}$ \\
\hline
\end{tabular}

IX. DISTRIBUTION AND AVAILABILITY

Copies of this report will be available from NIOSH, Division of Technical Services, Information Resources and Dissemination Section, 4676 Columbia Parkway, Cincinnati, Ohio 45226 for 90 days. Thereafter, copies will be available from the National Technical Information Service (NTIS), Springfield, Virginia. Information concerning its availability through NTIS can be obtained from NIOSH at the above Cincinnati address.

Copies of this report have been sent to:

1. Ottenheimer \& Sons, Incorporated, Dawson Springs, Kentucky

2. Amalgamated Clothing and Textile Workers Union, Local 888

3. ACTWU Director, Occupational Safety and Health

4. ACTWU Kentuckiana Joint Board

5. Kentucky State Department of Labor

6. Kentucky State Department of Health

7. U.S. Department of Labor, OSHA, Region IV

8. NIOSH, Region IV

For the purpose of informing the "affected employees" the employer shall post this report for at least 30 days in a prominent place(s) near where employees work. 
Airborne Concentrations of Formaldehyde

Ottenheimer \& Sons, Inc.

Dawson Springs, $\mathrm{Ky}$.

\begin{tabular}{|c|c|c|c|c|}
\hline $\begin{array}{l}\text { Date of } \\
\text { Sample }\end{array}$ & $\begin{array}{l}\text { Type of } \\
\text { Sample }\end{array}$ & Location of Sample & $\begin{array}{c}\text { Sample Volume } \\
\text { Liters } \\
\end{array}$ & $\begin{array}{c}\text { Airborne } \\
\text { Concentration - ppm } \\
\end{array}$ \\
\hline $6 / 23 / 77$ & General Area & Cutting Room & 271 & 0.20 \\
\hline $6 / 23 / 77$ & 11 & Sewing Machine & 244 & 0.57 \\
\hline $6 / 23 / 77$ & " & $"$ & 240 & 0.30 \\
\hline $3 / 13 / 78$ & General Area & Pressing Operation & 361 & 0.26 \\
\hline $3 / 13 / 78$ & $"$ & $"$ & 360 & 0.21 \\
\hline $3 / 13 / 78$ & Personal & Pressing Operation & 330 & 0.14 \\
\hline
\end{tabular}

Environmental Criteria: NIOSH $1.0 \mathrm{ppm}$ ceiling

OSHA $\quad 3.0$ ppm 8-hour TWA, 10 ppm ceiling 
Latent Formaldehyde Content of Cloth Samples

Ottenheimer \& Sons, Inc. Dawson Springs, Ky.

\begin{tabular}{llccc}
\hline \multicolumn{1}{c}{ Cloth } & Color & $\frac{\text { Latent Formaldehyde Content }- \text { ppm }}{3 / 21 / 78}$ & $\begin{array}{c}\% \\
\text { After }\end{array}$ & Decrease \\
Resolute & White & 938 & 86 & 91 \\
Valid Poplin & Blue & 912 & 88 & 90 \\
Resolute & Cherry Red & 700 & 70 & 90 \\
Valid Poplin & White & 580 & 84 & 86 \\
\hline
\end{tabular}

